UDC 1/14:7.01

Anna ASATRYAN

\title{
GEORG BRUTIAN AND NAS RA INSTITUTE OF ARTS
}

\begin{abstract}
The author recounts the cooperation of the academician Georg Brutian with the Institute of Arts, NAS RA. In particular, the scientific symposium, organized on the initiative of G. Brutian in the Institute of Arts on March 9, 2010 and dedicated to the $90^{\text {th }}$ anniversary of the world-renowned French painter of Armenian origin Jansem, as well as the booklet "Jansem-90", published the same year by the International Academy of Philosophy, the Armenian Academy of Philosophy and the Institute of Arts NAS RA and edited by the academician G. Brutian are spoken about.
\end{abstract}

Keywords: Georg Brutian, Institute of Arts NAS RA, creative cooperation, scientific conference, Jansem's jubilee.

On December 8, 2015, Georg Brutian, academician of the RA National Academy of Sciences, an outstanding philosopher and efficient organizer passed away. At once, three organizations - the International Institute of Argumentation, the Armenian Philosophical Academy and the International Academy for Philosophy - lost their leader ...

NAS RA Institute of Arts lost a great friend.

On the $90^{\text {th }}$ birthday (March 24, 2016) of academician G. Brutian, the management of NAS RA Institute of Arts visited the academician's grave and laid flowers.

Among academician G. Brutian's many talents, the best known was that for organizing science: back in 1977, he was elected academician-secretary of the Department of Philosophy and Philology of the Armenian Academy of Sciences; in 1994-2002 he was academician-secretary of NAS RA Department of Humanitarian Sciences, held the post of NAS RA vice-president. In those years, the Institute of Arts was part of the mentioned Department and, quite naturally, all the accomplishments of the Institute during that period of time were to a greater or lesser extent attributable to the strict and demanding, yet sympathizing and caring head of the Department.

In 2018, NAS RA Institute of Arts will celebrate 60 years of its founding. During these six decades it had but three directors, and they all enjoyed academician G. Brutian's favor. Thus, he played an important role in the scientific career of Ruben Zaryan, academician of the Arm. SSR Academy of Sciences, who headed the Institute from the day of its founding in 1958 through 1987, when he was removed from office upon his own application and appointed advisor to the directorate of the Institute of Arts, having recommended Levon Hakhverdyan as his substitute. On October 1,1987 , by the decision of the general 
meeting of NAS RA Department of Philosophy and Philology, Doctor of Philology Levon Hakhverdyan was appointed director of the Arm. SSR Institute of Arts.

Friendly relations between academician G. Brutian and NAS RA Institute of Arts continued through the days of Ararat Aghasyan, the third director of the Institute. Incidentally, it was on the initiative of G. Brutian that A. Aghasyan was elected as member to the Armenian Philosophical Academy.

The friendship between academician G. Brutian and NAS RA Institute of Arts was deeply rooted in the philosopher's love and appreciation of arts.

Taking advantage of the occasion, I would like to bring up an episode of cooperation between academician G. Brutian and NAS RA Institute of Arts. On May 9, 2010, on the initiative of G. Brutian, a scientific symposium, dedicated to the $90^{\text {th }}$ birth anniversary of the French Armenian internationally known painter Jansem (Hovhannes Semerdjian, March 9, 1920 - August 27, 2013) and NAS RA Foreign Member (2002), was held in the premises of NAS RA Institute of Arts. A telegram was sent to the hero of the event, which in particular said:

"Dear Master,

On behalf of the Armenian Philosophical Academy and the Institute of Arts of the National Academy of Sciences of the Republic of Armenia, on behalf of the participants of the symposium, dedicated to Your $90^{\text {th }}$ birthday anniversary, we extend our heartfelt wishes on this remarkable occasion.

Your art of profound ideal and visual content, broad genre and thematic scope and high artistic qualities has long taken its steady and solid place in the history of Armenian and the world fine arts of the XX century and our days. A hard worker of arts for decades, you have mastered all the secrets of painting, and thereby reached ultimate artistic craftsmanship. Your amazing and fascinating art has earned numerous admirers across the globe.

Dear Master, we know you as an individual of honest and bright soul, the talented and worthy son of the Armenian people.

On this anniversary day we wish you good health, long years of creative life, boundless vitality, wellbeing and personal happiness.

With best regards,

President of Armenian Philosophical

Academy,

Academician of NAS RA

Georg Brutian

Director of NAS RA Institute of Arts, Doctor of Arts, Professor

Ararat Aghasyan

March 9, 2010,

Yerevan." 1

On the occasion of the $90^{\text {th }}$ anniversary of Jansem, the booklet "Jansem - 90" was published in 2010 by the International Academy for Philosophy and NAS RA Institute of Arts, under the general editorship of academician G. Brutian.

In his address to the artist, dated March 9, 2010, the President of the Armenian Philosophical Academy G. Brutian particularly says: "Dear M. Jansem, on behalf of the presidium of the Armenian Philosophical Academy, the international community of philosophers and myself, I heartily wish You a very

1 See Archives of NAS RA Institute of Arts. 
happy $90^{\text {th }}$ birthday. The fact that Your art has earned you world fame and rightfully ranked you among the Immortals, fills our hearts with pride. We know you as not only a Great artist and painter, but also a true patriot of Armenia. The title of Honored Member of the Armenian Philosophical Academy, awarded to you years ago, evidences your exceptional role in the world of art, as well as the close association of Your art with philosophy, the philosophical framework and gist of Your wonderful oeuvre.

Dear Master of Masters, on the occasion of the $90^{\text {th }}$ anniversary of your birth, the Armenian Philosophical Academy decorates You with the most prestigious award of the Academy - the David Anhaght Medal. We also hope that You will accept our invitation to celebrate Your glorious $100^{\text {th }}$ anniversary in Yerevan.

President of the Armenian Philosophical Academy,

Academician Georg Brutian

March 9, 2010

Yerevan" (Brutian, 2010, p. 3).

Jansem first visited Armenia in 1973. His second visit to Armenia in 2001 was on the invitation of RA President Robert Kocharyan. The artist presented his "Genocide" series of 34 canvases (2000-2001) to the Armenian Genocide Museum-Institute. The series is exhibited in the special Jansem Hall opened in the Museum.

The first and last meeting of Jansem and academician G. Brutian took place in 2001 in Paris, the valuable remembrances of which, titled "A Meeting with Jean Jansem", are nar- rated in the "Jansem - 90" booklet, pages 1419 (see Ibid, pp. 14-19).

“... I was fortunate to meet with Jansem in person. Just once! We talked, or, rather, I listened to him talking, and thereby enriched my soul and thought. It happened in Paris in 2001. Just a single day, just a single time... Yet every time I make a mental visit to the world of art, I meet Jansem and continue our interrupted talk: I see what I had failed to see during our first meeting. The first meeting that was to be the last one. Let this not be perceived as pessimism. It is but realism. Both of us are in our advanced ages, and the distance between Paris and Yerevan is not so easy to cover.

As it usually happens, I became familiar with Jansem's works before I met him. That familiarization took place at rather extraordinary circumstances. Academicians F. Sargsyan, Em. Gabrielyan and I were in Japan, enjoying the hospitality of the world renowned artist, art historian, scientist, philosopher, in a word - the profusely gifted Goino-san. However, there was a flaw in him - his English was pretty poor, and his articulation was even poorer. Obviously, I should not have said anything like this about a person who had been doing his best to please us, his guests. Among others, he took us to a museum, whose name Goino-san pronounced with a strong Japanese accent, so none of us got any idea of whom it was about. The situation brought about arguments, our incorrect guesses took so much time that we left the museum without even seeing the exhibits.

It happened so that academician Goino invited me to a second visit to Japan, this time with my grandson Ara. With Ara's quick mind we realized that the museum is named 
after the great artist and our great compatriot Jansem. Incidentally, Jansem and Shahen Khachatryan did know about the museum, yet had never been to it. Who knows whether any Armenian from Armenia or Armenian diaspora has ever been to the Japanese city of Azumino 150 kilometers away from Tokyo, or is aware of that museum?

Later Jansem told me that there are two, not just one, museums of his works in Japan.

We talk... I prefer to be silent, to have a longer time to listen to Jansem. He stops, tired of talking. When he does not talk, he plays the violin. He has a powerful sensation of the languages of arts, and easily switches from the language of painting to that of music. This reminds me of the English mathematician Sawyer's teaching about the languages of science. Particularly, he maintains that it is very important to be able to switch from the language of algebra to that of geometry and vice versa. In the first case, the abstract symbols of algebra become understandable when a formula's content is translated into geometrical forms. The language of geometry makes visible the content of the algebraic formula. In the second case, we switch from the language of geometry to that of algebra to check how precisely the geometrical representations correlate with the algebraic problems.

I do not think Jean Jansem has read Sawyer. However, he has the innate sensation of the regularities discovered by the mathematician. In his own way, he transitions from the language of one art field to the language of another. This both relaxes him and gives power to solve his own fundamental problems. By the way, his love of the violin was so widely known that when, a year after our meeting, Jansem arrived in Yerevan, he re- ceived a violin as a gift from the famous violin master Martin Yeritsyan. The artist said he was very happy and could not even think of a better gift."

During their talk, G. Brutian reads some philosophical thoughts between the lines. "I do not think Jansem chose to speak so because he talked with a philosopher. His philosophical ideas about art sounded so naturally. I am convinced that whatever issue or field we touch upon in our conversation, the thoughts will be based on philosophical contexts. Although, there is a difference in to what extent the philosophical context seeks to become an overt text and to complete what has already been said openly. Such authors are usually labeled as "physicists-philosophers", "historian- philosophers", "artist- philosophers", etc.

My impression was that Jansem belongs to the painters whose artwork enriches not only fine arts, but also the overt and covert world of philosophic reflections."

At the very first elections held at the Armenian Philosophical Academy after the philosopher and the artist had met in Paris, Jean Jansem was elected as Honored Member of the Academy. G. Brutian imparted the news to the artist, whose response was not slow to arrive. The booklet brings both the original text in French and the Armenian translation:

“Dear Mr. President,' Jansem writes, 'I am touched and proud to hear I have been elected as Honored Member of the Armenian Philosophical Academy. I am grateful to You for this honor to belong to Your respected organization. Jean Jansem."

In 2002, Jansem was elected as Foreign Member of NAS RA. 
"Born and brought up beyond his fatherland Armenia', G. Brutian continues, 'Jansem's thoughts belong in Armenia, and his every heartbeat is dedicated to Armenia. The facts to prove this are plenty, yet I would like to first mention the creative enthusiasm, which drove him in his advanced age to create multiple canvases depicting the Armenian Genocide. The paintings make emotional not only those who condemn the Genocide, but every viewer. It is a scream of the soul, an outburst of concentrated thought and sensation, a deed of an individual whose fatherland is always within his heart. A deed that can deeply impress anybody. During his visit to Armenia, the Great artist and patriot presented these large-scale pictures, reproducing the horrors of the Armenian Genocide, to the Armenian Genocide Museum for permanent exhibition.
Our dear painter lives far from his fatherland Armenia, yet he, his oeuvre and spirit, are always here with us", G. Brutian concludes his recollections.

Jansem died on August 27, 2013, at the age of 93. Two years after, in 2015, academician G. Brutian passed away. Thanks to the booklet "Jansem - 90", two written documents and academician G. Brutian's valuable memories about the world famous artist were brought to the attention of academic circles.

\section{REFERENCES}

Brutian, G. (Ed.). (2010). Mi handipum Jhan Jhansemi het, Jhansem - 90 (A Meeting with Jean Jansem, Jansem 90, in Armenian), Yerevan: P'ilisop'ayut'yan mijazgayin akademiayi hratarakchut'yun. 